\title{
Elective neck dissection in oral squamous cell carcinoma of the upper maxilla: necessary?
}

\section{Manuel Moreno-Sánchez}

Department of Oral and Maxillofacial-Head and Neck Surgery, University Hospital Infanta Cristina, 06080 Badajoz, Spain. Correspondence Author: Dr. Manuel Moreno-Sánchez, Department of Oral and Maxillofacial-Head and Neck Surgery, University Hospital Infanta Cristina, Avenida de Elvas s/n, 06080 Badajoz, Spain. E-mail: manumorenosanchez@hotmail.com

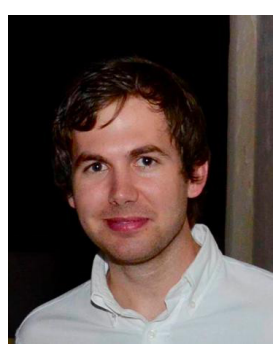

Dr. Manuel Moreno-Sánchez, M.D., obtained his Medical Degree at the University of Extremadura School of Medicine in Badajoz, Spain, in 2010. After that, he began to work as Resident Surgeon of Oral and Maxillofacial Surgery at the University Hospital Infanta Cristina, Badajoz, Spain. He is also University Honorary Collaborator at the University of Extremadura and he has completed a Master's Degree in Biomedicine. Currently, he is a postgraduate student at the Program of Modeling and Experimentation in Science and Technology of the University of Extremadura.

\begin{abstract}
Aim: Surgical treatment of clinically negative neck in maxillary squamous cell carcinoma (SCC) of the upper jaw is controversial. The purpose of this systematic review was to define the incidence of cervical metastasis and to assess if elective neck dissection is justified when the neck is not primarily affected. Methods: An electronic literature search was conducted in several databases, including MEDLINE, EMBASE, and Cochrane Central databases, for articles written in English. Results: Twenty-eight articles were included in the review. The overall cervical metastases rate was $33 \%$ and the total initial cervical metastases rate was $16 \%$. Interestingly, the author found that $71 \%$ of patients with cervical metastases from maxillary SCC carcinoma were T3/T4 stage. Conclusion: This review shows the need for a change in the management of the N0 neck in SCC arising in the maxillary alveolus and hard palate. Elective neck dissection should be performed in patients with T3/T4 tumours with clinic or radiographic negative necks (N0c).
\end{abstract}

Key words:

Elective neck dissection; maxilla squamous cell carcinoma; surgical treatment; cervical lymph node metastasis

\section{INTRODUCTION}

Squamous cell carcinoma (SCC) located in the maxillary gingiva and hard palate is relatively rare and less

\begin{tabular}{|l|l|}
\hline \multicolumn{2}{|c|}{ Access this article online } \\
\hline Quick Response Code: & Website: \\
\hline & http://www.parjournal.net \\
\cline { 2 - 3 } & \\
\hline
\end{tabular}

frequent than SCC from other oral sites such as tongue, floor of mouth or retromolar region. Many studies ${ }^{[1-5]}$

This is an open access article distributed under the terms of the Creative Commons Attribution-NonCommercial-ShareAlike 3.0 License, which allows others to remix, tweak and build upon the work non-commercially, as long as the author is credited and the new creations are licensed under the identical terms.

For reprints contact: service@oaepublish.com

How to cite this article: Moreno-Sánchez M. Elective neck dissection in oral squamous cell carcinoma of the upper maxilla: necessary? Plast Aesthet Res 2016;3:175-80.

Received: 02-04-2016; Accepted: 02-06-2016 
Table 1: Studies included in the review about patients with squamous cell carcinoma of the upper maxilla

\begin{tabular}{|c|c|c|c|c|c|c|c|c|}
\hline Author & Year & Country & $\begin{array}{c}\text { No. of } \\
\text { patients }\end{array}$ & Study & $\begin{array}{c}\text { Nodal } \\
\text { disease in } \\
\text { T3/T4 (\%) }\end{array}$ & $\begin{array}{c}\text { Initial } \\
\text { nodal } \\
\text { disease } \\
(\%)\end{array}$ & $\begin{array}{c}\text { Overal } \\
\text { nodal } \\
\text { disease } \\
\text { incidence } \\
(\%)\end{array}$ & $\begin{array}{l}\text { Follow-up } \\
\text { (months) }\end{array}$ \\
\hline Truitt et al..$^{[23]}$ & 1999 & USA & 24 & Retrospective & Unknown & $17 \%$ & $33 \%$ & 60 \\
\hline Ogura et al..$^{[14]}$ & 2003 & Japan & 21 & Retrospective & Unknown & $29 \%$ & $67 \%$ & Unknown \\
\hline Simental et al. ${ }^{[11]}$ & 2006 & USA & 26 & Retrospective & Unknown & $12 \%$ & $35 \%$ & 65 \\
\hline Zwetyenga et al. $^{[35]}$ & 2006 & France & 34 & Retrospective & $91 \%$ & $18 \%$ & $32 \%$ & Unknown \\
\hline Montes and Schmid ${ }^{[9]}$ & 2008 & USA & 14 & Retrospective & $50 \%$ & $21 \%$ & $43 \%$ & 27 \\
\hline Lin and Bhattacharyya ${ }^{[22]}$ & 2009 & USA & 725 & Cross-section & $64 \%$ & $14 \%$ & $14 \%$ & Unknown \\
\hline Kruse and Grätz ${ }^{[12]}$ & 2009 & Switzerland & 30 & Retrospective & $18 \%$ & $13 \%$ & $37 \%$ & Unknown \\
\hline Mourouzis et al. ${ }^{[13]}$ & 2010 & UK & 17 & Retrospective & $100 \%$ & $24 \%$ & $35 \%$ & 60 \\
\hline Montes et al..$^{[16]}$ & 2011 & USA & 131 & Retrospective & $55 \%$ & $24 \%$ & $31 \%$ & $1-180$ \\
\hline Lubek et al. ${ }^{[18]}$ & 2011 & USA & 37 & Retrospective & $67 \%$ & $5 \%$ & $16 \%$ & 49 \\
\hline Nicolai et al. ${ }^{[34]}$ & 2010 & Italy & 86 & Retrospective & $31 \%$ & $9 \%$ & $22 \%$ & Unknown \\
\hline Wang et al. ${ }^{[36]}$ & 2010 & Taiwan & 79 & Retrospective & $100 \%$ & $9 \%$ & $22 \%$ & Unknown \\
\hline Valentini et al. ${ }^{[25]}$ & 2010 & Italy & 19 & Retrospective & Unknown & $5 \%$ & $11 \%$ & Unknown \\
\hline Beltramini et al. ${ }^{[26]}$ & 2012 & Italy & 65 & Retrospective & $86 \%$ & $12 \%$ & $22 \%$ & 43.3 \\
\hline Morris et al. ${ }^{[15]}$ & 2011 & USA & 139 & Retrospective & $71 \%$ & $8 \%$ & $31 \%$ & 57 \\
\hline Brown et al. ${ }^{[10]}$ & 2013 & UK & 43 & Retrospective & $81 \%$ & $7 \%$ & $37 \%$ & 94 \\
\hline Poeschl et al. ${ }^{[33]}$ & 2012 & Austria & 74 & Retrospective & $100 \%$ & Unknown & $22 \%$ & $6-130$ \\
\hline Dalal and McLennan ${ }^{[30]}$ & 2013 & UK & 30 & Retrospective & $100 \%$ & $27 \%$ & $36 \%$ & 60 \\
\hline Feng et al. ${ }^{[27]}$ & 2013 & China & 129 & Retrospective & $65 \%$ & $0 \%$ & $24 \%$ & Unknown \\
\hline Eskander et al. ${ }^{[32]}$ & 2013 & Canada & 97 & Cohort & $53 \%$ & $24 \%$ & $41 \%$ & Unknown \\
\hline Sagheb et al. ${ }^{[29]}$ & 2014 & Germany & 138 & Retrospective & $60 \%$ & $38 \%$ & $46 \%$ & 43 \\
\hline Zhang et al. ${ }^{[37]}$ & 2015 & China & 100 & Retrospective & $79 \%$ & $9 \%$ & $34 \%$ & 46 \\
\hline Philip et al. ${ }^{[24]}$ & 2014 & UK & 39 & Retrospective & $95 \%$ & $33 \%$ & $46 \%$ & 38 \\
\hline Givi et al. ${ }^{[39]}$ & 2016 & USA & 199 & Retrospective & $50 \%$ & $6 \%$ & $22 \%$ & 52 \\
\hline Berger et al. ${ }^{[40]}$ & 2015 & Germany & 171 & Retrospective & $78 \%$ & Unknown & $44 \%$ & Unknown \\
\hline Yang et $a^{[28]}$ & 2015 & China & 62 & Retrospective & $69 \%$ & $15 \%$ & $37 \%$ & 37 \\
\hline Troeltzsch et al. ${ }^{[41]}$ & 2016 & Germany & 92 & Retrospective & $40 \%$ & $16 \%$ & $29 \%$ & 42 \\
\hline Moreno-Sánchez et al..$^{[42]}$ & 2016 & Spain & 20 & Retrospective & $100 \%$ & $30 \%$ & $45 \%$ & 53 \\
\hline
\end{tabular}

have evaluated the need for elective neck dissection in these intraoral common sites when there is no clinical or radiographic suspicious of lymphadenopathy. ${ }^{[6-10]}$ Controversies remain regarding the strategy of treatment for patients with maxillary SCC, ${ }^{[11-15]}$ including indications for unilateral or bilateral elective neck dissection and postoperative adjuvant treatment. ${ }^{[16-20]}$ Only a few authors ${ }^{[21-25]}$ have focused on the management of the neck in SCC of the maxillary gingiva, maxillary alveolus and hard palate..$^{[26-30 \mid}$

Traditionally, when there is no clinical or radiographic suspicious of lymphadenopathy, management has been to watch and wait. However, in recent studies, ${ }^{\mid 31-35]}$ it has been proven that a higher rate of occult cervical metastases in SCC of the maxilla has been found ${ }^{|36-40|}$ and elective neck dissection in these patients has been recommended in order to reduce recurrences. ${ }^{[41-43]}$

A systematic review was conducted in order to clarify if elective neck dissection is necessary in management of SCC of the maxillary gingiva, maxillary alveolus and hard palate, and to identify the risk of cervical metastases in patients with maxillary SCC.

\section{METHODS}

An electronic literature search was conducted in several databases, including MEDLINE, EMBASE, and Cochrane Central databases, for articles written in English from their respective dates of inception to December 2015. The searching keywords were "cervical metastases" OR "cervical metastases" OR "neck metastases" AND "maxillary squamous cell carcinoma" OR "maxilla squamous cell carcinoma" OR "squamous cell carcinoma of upper maxilla" AND (limit to clinical trial OR randomized controlled trial).

The abstracts of yielded results were reviewed and the full text of those with apparent relevance was obtained. The references of identified articles were crosschecked for unidentified articles. These journals were Journal of Oral and Maxillofacial Surgery; International Journal of Oral and Maxillofacial Surgery; Journal of Oral Surgery; British Journal of Oral and Maxillofacial Surgery; Head and Neck Surgery; Laryngoscope; Oral Oncology; Journal of CranioMaxillo-Facial Surgery; Oral Surgery, Oral Medicine, Oral Pathology and Oral Radiology; and Revista Española de Cirugía Oral y Maxilofacial. The searches were limited to articles 


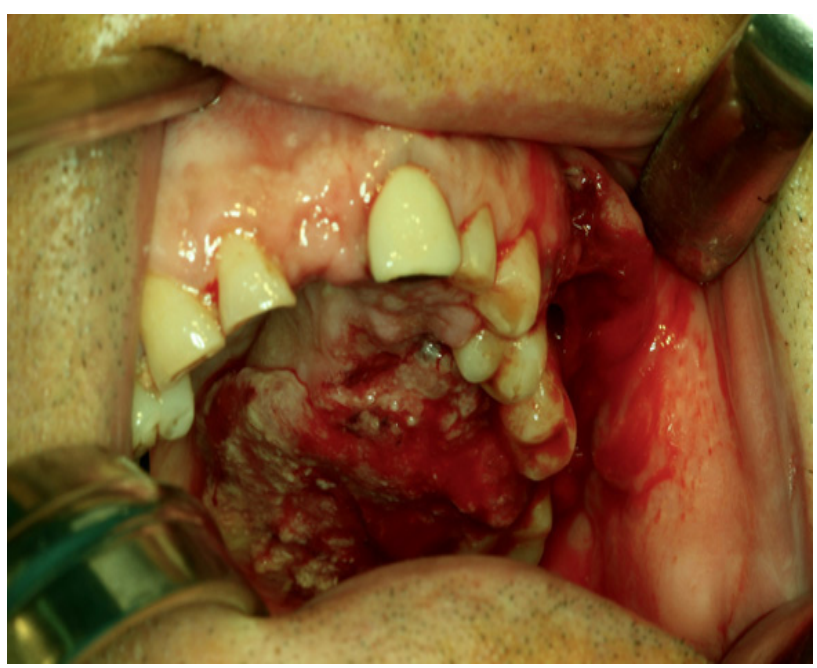

Figure 1: Intraoperative photograph of a patient with T4 squamous cell carcinoma of the hard palate with cervical metastases

published in English. The PICO question was as follows: is elective neck dissection necessary in oral squamous cell carcinoma of the upper maxilla?

The following exclusion criteria were applied: (1) case reports; (2) technical reports; (3) animal or in vitro studies; (4) review articles; (5) uncontrolled clinical studies; and (6) publications in which the same data were published by the same group of researchers. The authors carefully assessed the eligibility of all studies retrieved from the databases. From the included studies in the final analysis, the following data were extracted: authors, year of publication, country, study design, number of patients in the groups, initial nodal disease (\%), and nodal disease in T3/T4 stage (\%), overall nodal disease incidence (\%) and follow-up period.

The selected articles were used to assess the rate of cervical metastases in patients with squamous cell carcinoma of the upper maxilla.

\section{RESULTS}

The electronic search resulted in 502 entries. Four additional articles were identified by manual searching. Of the 502 articles identified by electronic search, 305 were excluded because they were being retrieved in more than one search. After the initial screening of titles and abstracts, 169 articles were excluded because they were off topic. Thus, 28 articles were included in the review.

Of the 28 articles, 26 were retrospective studies, 1 was a cohort study, and 1 was a cross-sectional study. The studies included 2,641 cases in total [Table 1].

\section{Rates of total cervical metastases}

The rates of total cervical metastases were analysed in 28 articles [Table 1] in which metastases was confirmed by pathological examination. The overall metastases rate was defined as the ratio between the number of
$\mathrm{pN}+$ cases and total cases. For the patients without neck dissection initially, those presenting with regional metastases or recurrence during the follow-up period would also be counted as $\mathrm{pN}+$ cases. Several authors reported high rate of total cervical metastases. In a recent study, Berger et al. ${ }^{[40]}$ reported $44 \%$ of total cervical metastases in a series of 171 patients. Yang et al. ${ }^{[31]}$ observed a $37 \%$ of patients with cervical metastases during the follow-up in a series of 62 patients. Eskander et al ${ }^{[32}$ reported a total of $41 \%$ of cervical metastases in a wellstructured study of a 97 patients. Montes and Schmidt ${ }^{[9]}$ reported a $42.9 \%$ rate of regional nodal disease in a series of 14 patients. Brown et al. ${ }^{[10]}$ reported a rate of $37.2 \%$ in a series of 43 patients.

We can conclude from our meta-analysis about these 28 studies including 2,641 patients that the overall cervical metastases from SCC of the upper maxilla are 33\%.

\section{Initial nodal disease}

Initial nodal disease was defined as the patients with lymph neck node metastases from the physical and radiologic examination in the first examination and the overall initial metastases rate was defined as the ratio between the number of initial $\mathrm{cN}+$ cases and total cases. This variable was analysed in 26 of the 28 articles [Table 1]. At the time of the primary diagnosis, in a series of 138 patients, Sagheb et al. ${ }^{[29]}$ observed 52 (38\%) with cervical metastases whereas $53(38 \%)$ patients that had a T3 (n $=6)$ or T4 $(n=47)$ tumour as well. Philip and James ${ }^{[24]}$ reported $33 \%(13)$ of patients with neck disease at presentation. Ogura et al. ${ }^{[14]}$ observed $28.5 \%$ of cervical metastases at presentation in their series of 21 patients with SCC of the upper maxilla. Dalal and McLennan ${ }^{[30}$ reported a $27 \%$ of cervical metastases at initial diagnosis.

From our meta-analysis among 26 studies including 2,396 patients with SCC of the upper maxilla, we can conclude that the overall initial cervical metastases rate is $16 \%$.

\section{T3/T4 nodal rate}

We also analysed the incidence of cervical metastases of maxillary SCC in advanced-stage (T3/4) disease, including 24 articles for this purpose. Interestingly, we observed that the probability of lymph node metastases increased with the size of the tumour. Brown et al. ${ }^{[10]}$ reported an $81 \%$ of cervical metastases in T3/T4 tumours in a series of 43 patients and Berger et al..$^{[40]}$ observed a $78 \%$ of cervical metastases in patients with T3/T4 stage in a series of 171 patients. Philip and James ${ }^{[24]}$ observed a 95\% of cervical metastases in T3/T4 tumours. Even authors such as Poeschl et al. ${ }^{[33]}$ or Dalal and McLennan ${ }^{[30]}$ reported that all the patients $(100 \%)$ with advanced-stage (T3/T4) developed cervical metastases.

From our meta-analysis these 24 studies including 2,551 patients, we observed that $71 \%$ of patients with cervical 


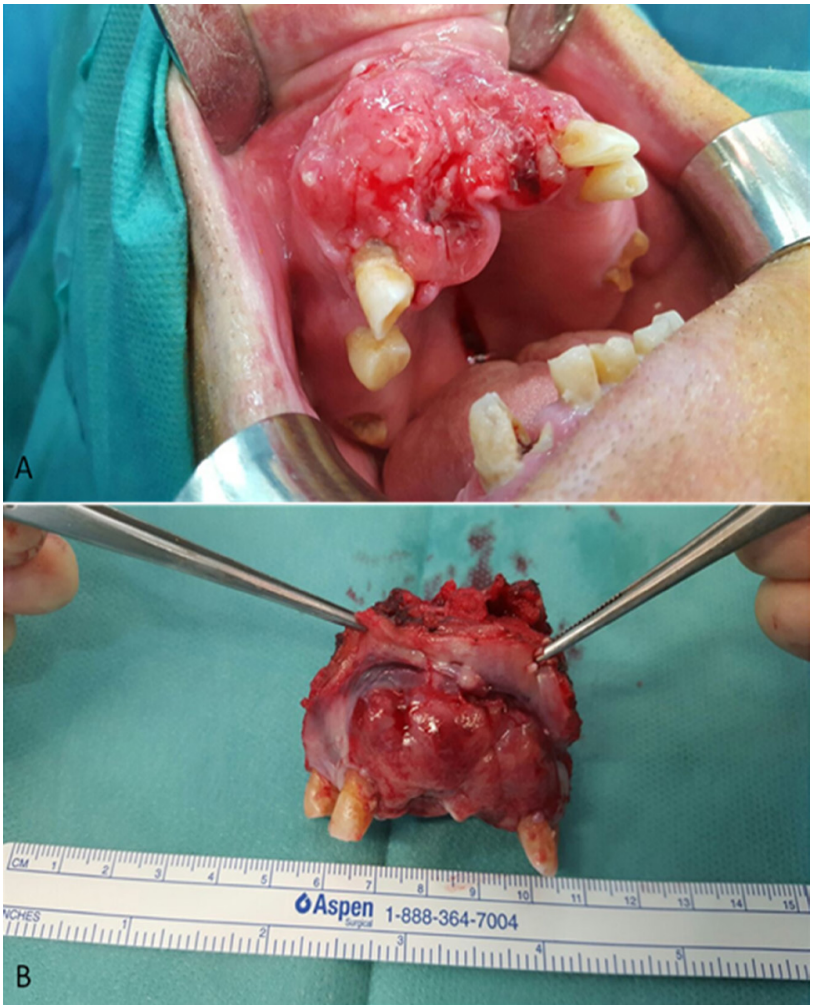

Figure 2: (A) Intraoperative photograph of a patient with T4 squamous cell carcinoma of the maxillary gingiva and bone invasion; (B) maxillary tumour was resected with wide surgical margins

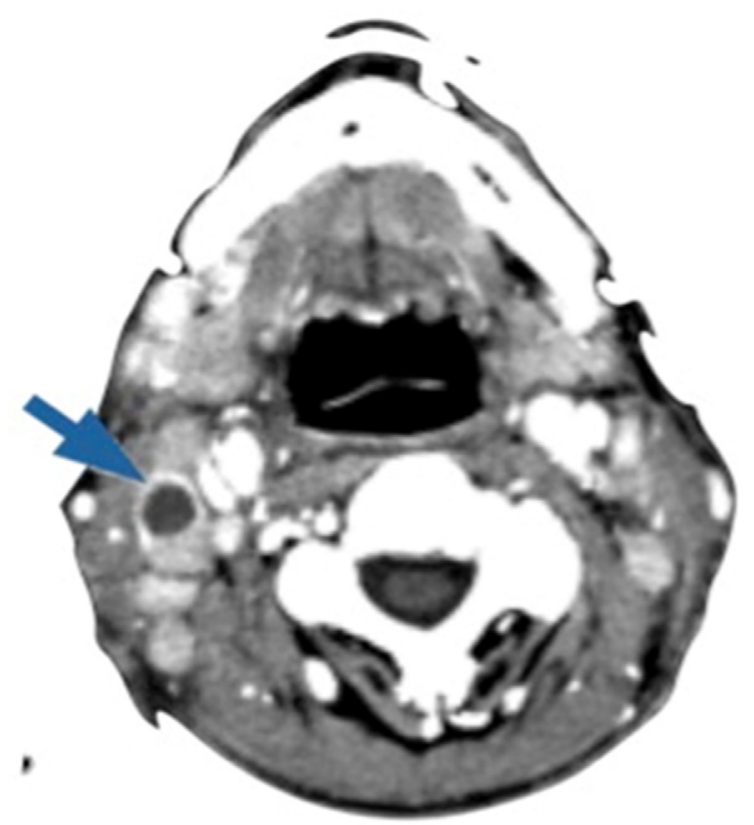

Figure 3: Computed tomography of the neck showing a cervical metastasis (arrow) of maxillary squamous cell carcinoma

metastases from maxillary SCC carcinoma were T3/T4 stage [Table 1].

\section{DISCUSSION}

In the last century, few studies have been focused on cervical metastases from SCC of the maxilla. Nevertheless, cervical metastases from SCC of tongue or floor of mouth have been well studied, both sites presenting a high incidence, considering elective neck dissection necessary in patients.

Elective neck dissection is generally performed in patients with SCC of the oral cavity when there is a risk of occult metastases higher than $15 \%$. It is made at the time of surgery of the primary tumour, since most cancers of the oral cavity are treated surgically. ${ }^{[1-5]}$ The risk of cervical metastases of maxillary gingival and hard palate SCC is considered lower than metastases of SCC in other primary sites, and management of clinical NO (cN0) patients is to "watch and wait". The National Comprehensive Cancer Network proposed guidelines for treatment strategies for head and neck cancer, suggesting selective neck dissection for cN0 patients with SCC of the tongue, floor of the mouth, mandibular gingiva, and buccal mucosa. ${ }^{[4]}$ However, there is still no specific strategy for cNO cases of maxillary SCC.

Recently, several studies reported that cervical metastases of maxillary SCC are much higher than expected and comparable to that of other primary oral sites. Montes and Schmidt ${ }^{[9]}$ reported a $42.9 \%$ rate of regional nodal disease in a series of 14 patients with SCC of the maxilla; Brown et al. ${ }^{[10]}$ reported a rate of $37.2 \%$ in a series of 43 patients; Simental et al. ${ }^{[11]}$ in a series of 26 patients with SCC of the maxillary alveolus and hard palate found cervical metastases in $34.6 \%$, similar to that observed by Kruse and Grätz ${ }^{[12]}(33.6 \%)$ in a series of 30 patients. Mourouzis et al. ${ }^{[13]}$ reported a $23.5 \%$ incidence of cervical metastases at presentation with maxillary SCC in a series of 17 patients. These reported incidences of cervical metastases are comparable to those observed for SCC of tongue or floor of mouth. Ogura et al. ${ }^{[14]}$ reported a $28.5 \%$ incidence of cervical disease at presentation. Recently, Berger et al. ${ }^{[40]}$ reported an overall rate of $44 \%$ of cervical metastases in a series of 171 patients. In our series, we founded that 9 of the 20 (45\%) patients with SCC involving the palate or the maxillary alveolus [Figures 1 and 2] developed cervical metastases [Figure 3] during disease. ${ }^{[42]}$

In the 28 articles included in this systematic review, the initial nodal disease was $16 \%$ and cervical metastases rate ranged from $11 \%$ to $67 \%$ with an overall metastases rate of $33 \%$ in a total of 2,641 patients, which was similar to the cervical metastases from SCC of other oral sites, such as the tongue or floor of the mouth.

According to the tumour node metastasis classification system, T represents tumour size, depth of invasion, and relation with the surrounding tissue. The association between tumour site, size and grading and the risk of lymphatic metastases is well known for SCC of oral cavity and is not different for SCC of the maxilla. ${ }^{[44]}$ 
It is very significant that most of cervical metastases from SCC of the maxilla in the analysed series (71\%) corresponded with a tumour size larger than $4 \mathrm{~cm}$ (T3 and $\mathrm{T} 4$ tumours). This rate of cervical metastases from big-sized tumours may suggest performing elective neck dissection only in patients with advanced disease. This finding has been observed by an American multicenter study by Montes et al ${ }^{[16]}$ about maxillary SCC, which reported a high percentage of cervical metastases in T3 and T4 tumours. Meng et al., ${ }^{[21]}$ in their series of 78 patients with SCC of the maxilla, reported that rates for positive nodal metastases from T1 and T2 tumours were lower than $15 \%$, whereas those for $\mathrm{T} 3$ and $\mathrm{T} 4$ tumours were higher than $40 \%$. Zhang et al. ${ }^{[37]}$ in a series of 100 patients, observed a $79 \%$ of cervical metastases in patients with T3/T4 SCC of the upper maxilla. Brown et al. ${ }^{[10]}$ reported an $81 \%$ of cervical metastases in T3/T4 tumours in a series of 43 patients, while Berger et al. ${ }^{[40]}$ in a series of 171 patients, observed a $78 \%$ of cervical metastases in patients with T3/T4 stage. Even others authors have reported that all the patients $(100 \%)$ with advanced-stage (T3/T4) developed cervical metastases in some point during the study. ${ }^{[13,30,33,42]}$

Within our meta-analysis, in 24 out of 28 articles, metastases in patients with T3/T4 tumours were analysed, founding a total of $71 \%$ of cervical metastases. These data could demonstrate a significant connection between T-stage and metastatic cervical status, and may suggest that patients with advanced-stage (T3/4) disease face a significantly higher risk of metastases.

It is a fact that most clinicians do not routinely perform elective neck dissection when the neck is clinically or radiographically negative. However, the results from our systematic review suggest that elective neck dissection should be performed in patients with locally advanced SCCs of the hard palate and maxillary alveolus, despite the fact that SCC of these sites has traditionally been believe to have a low rate of occult metastases.

In spite of the results observed from this meta-analysis, we believe that it is important to highlight that most of the analysed studies are retrospective, with their intrinsic limitations. Furthermore, several papers are limited by the small number of patients enrolled in the study. Therefore, prospective studies with larger series are necessary.

In conclusion, this systematic review shows the fact that the rate of metastases in patients with SCC of the upper maxilla is high and comparable with metastases from other oral cavity cancers. Thus, the authors believe in the need for a change in the management of the NO neck in SCC arising in the maxillary alveolus and hard palate. Elective neck dissection should be performed in patients with T3/T4 tumours with clinic or radiographic negative necks (NOc). Prospective studies with a large number of patients are necessary to confirm the results obtained from this study.

\section{Financial support and sponsorship}

Nil.

\section{Conflicts of interest}

There are no conflicts of interest.

\section{REFERENCES}

I. Shah JP, Candela FC, Poddar AK. The patterns of cervical lymph node metastases from squamous carcinoma of the oral cavity. Cancer 1990;66:109-13.

2. Woolgar JA. Histological distribution of cervical lymph node metastases from intraoral/oropharyngeal squamous cellcarcinomas. Br J Oral Maxillofac Surg 1999;37:175-80.

3. González-García R, Naval-Gías L, Román-Romero L, Sastre-Pérez J, Rodríguez-Campo FJ. Local recurrences and second primary tumors from squamous cell carcinoma of the oral cavity: a retrospective analytic study of 500 patients. Head Neck 2009;3 I: I I 68-80.

4. Kowalski LP, Bagietto R, Lara JR, Santos RL, Tagawa EK, Santos IR. Factors influencing contralateral lymph node metastasis from oral carcinoma. Head Neck 1999;2 I: I04-I0.

5. Weiss $\mathrm{MH}$, Harrison LB, Isaacs RS. Use of decision analysis in planning a management strategy for the stage N0 neck. Arch Otolaryngol Head Neck Surg 1994;120:699-702.

6. Capote A, Escorial V, Muñoz-Guerra MF, Rodriguez-Campo FJ, Gamallo C, Naval L. Elective neck dissection in early-stage oral squamous cell carcinoma-does it influence recurrence and survival? Head Neck 2007;29:3-II.

7. Hiratsuka H, Miyakawa A, Nakamori K, Kido Y, Sunakawa H, Kohama G. Multivariate analysis of occult lymph node metastasis as a prognostic indicator for patients with squamous cell carcinoma of the oral cavity Cancer 1997;80:351-6.

8. Yuen AP, Ho CM, Chow TL, Tang LC, Cheung WY, Ng RW, Wei WI, Kong CK, Book KS, Yuen WC, Lam AK, Yuen NW, Trendell-Smith NJ, Chan YW, Wong BY, Li GK, Ho AC, Ho WK, Wong SY, Yao TJ Prospective randomized study of selective neck dissection versus observation for NO neck of early tongue carcinoma. Head Neck 2009;31:765-72.

9. Montes DM, Schmidt BL. Oral maxillary squamous cellcarcinoma: management of the clinically negative neck. J Oral Maxillofac Surg 2008;66:762-6.

10. Brown JS, Bekiroglu F, Shaw RJ, Woolgar JA, Rogers SN. Management of the neck and regional recurrence in squamous cell carcinoma of the maxillary alveolus and hard palate compared with other sites in the oral cavity. Head Neck 2013;35:265-9.

II. Simental AA, Johnson JT, Myers EN. Cervical metastasis from squamous cell carcinoma of the maxillary alveolus and hard palate. Laryngoscope 2006; I 16:1682-4.

12. Kruse AL, Grätz KW. Cervical metastases of squamous cellcarcinoma of the maxilla: a retrospective study of 9 years. Head Neck Oncol 2009;20:I-28.

13. Mourouzis C, Pratt C, Brennan PA. Squamous cell carcinoma of the maxillary gingiva, alveolus, and hard palate: is there a need for elective neck dissection? Br J Oral Maxillofac Surg 2010;48:345-8.

14. Ogura I, Kurabayashi T, Sasaki T, Amagasa T, Okada N, Kaneda T. Maxillary bone invasion by gingival carcinoma as an indicator of cervical metastasis. Dentomaxillofac Radiol 2003;32:291-4.

15. Morris LG, Patel SG, Shah JP, Ganly I. High rates of regional failure in squamous cell carcinoma of the hard palate and maxillary alveolus. Head Neck 20I I;33:824-30.

16. Montes DM, Carlson ER, Fernandes R, Ghali GE, Lubek J, Ord R, Bell B, Dierks E, Schmidt BL. Oral maxillary squamous carcinoma: an indication for neck dissection in the clinically negative neck. Head Neck 20I I;33:158I-5.

17. Kermer C, Poeschl PW, Wutzl A, Schopper C, Clemens K, Poeschl E. Surgical treatment of squamous cell carcinoma of the maxilla and 
nasal sinuses. J Oral Maxillofac Surg 2008;66:2449-53.

18. Lubek J, El-Hakim M, Salama AR, Liu X, Ord RA. Gingival carcinoma: retrospective analysis of 72 patients and indications for elective neck dissection. Br J Oral Maxillofac Surg 201 I;49:182-5.

19. Haddadin KJ, Soutar DS, Oliver RJ, Webster MH, Robertson AG, MacDonald DG. Improved survival for patients with clinicallyTI/T2, No tongue tumors undergoing a prophylactic neck dissection. Head Neck 1999;21:517-25.

20. Woolgar JA, Scott J. Prediction of cervical lymph node metastasis in squamous cell carcinoma of the tongue/floor of mouth. Head Neck 1995; 1 7:463-72.

21. Meng FY, Ko JY, Lou PJ, Wang CP, Yang TL, Chang CH, Chang YL, Chen TC. The determining risk factors for treatment outcomes in patients with squamous cell carcinoma of the hard palate. Ann Surg Oncol 2012;19:2003-10.

22. Lin HW, Bhattacharyya N. Survival impact of nodal disease in hard palate and maxillary alveolus cancer. Laryngoscope 2009; I 19:3 I2-I5.

23. Truitt TO, Gleich LL, Huntress GP, Gluckman JL. Surgical management of hard palate malignancies. Otolaryngol Head Neck Surg 1999; I 2 1:54852.

24. Philip J, James R. Maxillary squamous cell carcinoma: an I I-year retrospective study of one regional cancer centre. Int J Oral Maxillofac Surg 2014;43: I195-8.

25. Valentini V, Terenzi V, Battisti A, Cassoni A, Anelli A, Priore P, Petrinca P. Management of clinically negative neck in maxillary carcinoma.J Craniofac Surg 2010;21:759-62.

26. Beltramini GA, Massarelli O, Demarchi M, Copelli C, Cassoni A, Valentini V, Tullio A, Giannì AB, Sesenna $E$, Baj $A$. Is neck dissection needed in squamous-cell carcinoma of the maxillary gingiva, alveolus, and hard palate? A multicentre Italian study of 65 cases and literature review. Oral Oncol 20I2;48:97-I0I.

27. Feng Z, Li JN, Li CZ, Guo CB. Elective neck dissection versus observation for cN0 neck of squamous cell carcinoma primarily located in the maxillary gingiva and alveolar ridge: a retrospective study of 129 cases. Oral Surg Oral Med Oral Pathol Oral Radiol 2013;116:556-6I.

28. Yang X, Song X, ChuW, Li L, Ma L, Wu Y. Clinicopathological characteristics and outcome predictors in squamous cell carcinoma of the maxillary gingiva and hard palate. J Oral Maxillofac Surg 2015;73:1429-36.

29. Sagheb K, Sagheb K, Taylor KJ, Al-Nawas B, Walter C. Cervical metastases of squamous cell carcinoma of the maxilla: a retrospective study of 25 years. Clin Oral Investig 2014; 18:1221-7.

30. Dalal AJ, McLennan AS. Cervical metastases from maxillary squamous cell carcinoma: retrospective analysis and review of the literature. $\mathrm{Br}$ J Oral Maxillofac Surg 2013;51:702-6.

31. Yang Z, Deng R, Sun G, Huang X, Tang E. Cervical metastases from squamous cell carcinoma of hard palate and maxillary alveolus: a retrospective study of 10 years. Head Neck 20I4;36:969-75.

32. Eskander A, Givi B, Gullane PJ, Irish J, Brown D, Gilbert RW, Hope A, Weinreb I, Xu W, Goldstein DP. Outcome predictors in squamous cell carcinoma of the maxillary alveolus and hard palate. Laryngoscope
20|3;| 23:2453-8.

33. Poeschl PW, Seemann R, Czembirek C, Russmueller G, Sulzbacher I, Selzer E, Selzer E, Nuhic D, Ewers R. Impact of elective neck dissection on regional recurrence and survival in $\mathrm{CN} 0$ staged oral maxillary squamous cell carcinoma. Oral Oncol 2012;48:173-8.

34. Nicolai G, Lorè B, Prucher G, De Marinis L, Calabrese L. Treatment of $\mathrm{N}$ in the upper maxillary tumors. J Craniofac Surg 2010;21:1798800 .

35. Zwetyenga N, Miquel L, Garuet A, Ricard AS, Majoufre-Lefebvre C, Demeaux $H$, Siberchicot F. Treatment of squamous-cell carcinoma of the upper gum and the hard palate. Rev Stomatol Chir Maxillofac 2006; 107:80-5.

36. Wang TC, Hua CH, Lin CC, Tsou YA, Tseng HC, Tsai MH. Risk factors affect the survival outcome of hard palatal and maxillary alveolus squamous cell carcinoma: 10-year review in a tertiary referral center. Oral Surg Oral Med Oral Pathol Oral Radiol Endod 2010; I 10: I I-7.

37. Zhang WB, Wang Y, Mao C, Guo CB, Yu GY, Peng X. Cervical metastasis of maxillary squamous cell carcinoma. Int J Oral Maxillofac Surg 2015;44:285-91.

38. Binahmed A, Nason RW, Hussain A, Abdoh AA, Sándor GK. Treatment outcomes in squamous cell carcinoma of the maxillary alveolus and palate:a population-based study. Oral Surg Oral Med Oral Pathol Oral Radiol Endod 2008; 105:750-54.

39. Givi B, Eskander A, Awad M, Kong Q, Montero PH, Palmer FL, Xu W, De Almeida JR, Lee N, O'Sullivan B, Irish JC, Gilbert R, Ganly I, Patel SG, Goldstein DP, Morris LG. Impact of elective neck dissection on the outcome of oral squamous cell carcinomas arising in the maxillary alveolus and hard palate. Head Neck 2016;38 Suppl I:EI68894.

40. Berger M, Grau E, Saure D, Ristow O, Thiele O, Hofele C, Hoffmann J, Seeberger R, Freier K. Occurrence of cervical lymph node metastasis of maxillary squamous cell carcinoma-A monocentric study of I7| patients. J Cranio Maxillofac Surg 2015;43:2195-9.

41. Troeltzsch M, Knösel T, Woodlock T, Troeltzsch M, Pianka A, Probst FA, Mast G, Ehrenfeld M, Otto S. Are there clinical or pathological parameters of maxillary oral squamous cell carcinoma with an influence on the occurrence of neck node metastasis? An appraisal of 92 patients. J Oral Maxillofac Surg 2016;74:79-86.

42. Moreno-Sánchez M, González-García R, González-Ballester D, RuizLaza L, Moreno-García C, Monje F. What is the role of elective neck dissection in patients with squamous cell carcinoma of the upper jaw? Rev Esp Cir Oral Maxilofac 2016; doi:10.1016/j.maxilo.2016.02.003.

43. Robbins KT, Clayman G, Levine PA, Medina J, Sessions R, Shaha A, Som P,Wolf GT; American Headand Neck Society; American Academy of Otolaryngology-Head and Neck Surgery. Neck dissection classification update: revisions proposed by the American Head and Neck Society and the American academy of Otolaryngology-Head and Neck Surgery. Arch Otolaryngol Head Neck Surg 2002; I 28:5 I-8.

44. Webber C, Gospodarowicz M, Sobin LH, Wittekind C, Greene FL, Mason MD, Compton C, Brierley J, Groome PA. Improving the TNM classification: findings from a 10 -year continuous literature review. Int J Cancer 2014;135:37|-8. 